\title{
Penguatan Pendidikan Karakter Di Era Industri 4.0: Optimalisasi Pendidikan Agama Islam Di Sekolah
}

\author{
Muhammad Kosim ${ }^{1}$ \\ 1Universitas Islam Negeri Imam Bonjol Padang \\ muhammadkosim@uinib.ac.id
}

\begin{abstract}
\section{Keywords:}

strengthening

of character

education in

schools;

Islamic

education;

industrial

revolution 4.0

Advances in information and communication technology in the Digital Revolution Era, in addition to positive impacts, also had a negative impact on human character, such as individualist, materialist attitudes, and even rejecting spiritual aspects. Therefore, we need the concept of Strengthening Character Education by optimizing the role of Islamic Religious Education in Schools to educate students who have faith, taqwa, and have good character according to their fitrah. To answer this need, a library research study was conducted which analyzed several papers that were relevant to the hermeneutic approach and content analysis method. This article finds that the optimization of Islamic Religious Education in Strengthening of Character Education in schools can be done by: first, strengthening the character of Muslim teachers who emulate the character of the Prophet SAW as a true educator; secondly, optimization of Islamic Religious Education in Classbased Strengthening Character Education with a tauhid-based science paradigm, integrating Islamic values in learning, and strengthening Islamic Religious Education materials in schools; third, optimization of Islamic Religious Education in school-based Strengthening Character Education by implementing the concept of taqwa-based Islamic education and making surau as a character labor; and fourth, the optimization of Islamic Religious Education in community-based Strengthening Character Education by organizing Islamic parenting and school collaboration with parents and the community in strengthening the character of students.
\end{abstract}

Kata Kunci:

penguatan pendidikan karakter di sekolah; pendidikan agama
Abstrak:

Kemajuan teknologi informasi dan komunikasi Era Revolusi Digital, di samping dampak positif, juga berdampak negatif terhadap karakter manusia, seperti sikap individualis, materialis, hingga mengabaikan aspek spiritual. Karena itu, diperlukan 
Islam; revolusi industri 4.0

\begin{abstract}
gagasan Penguatan Pendidikan Karakter dengan mengoptimalkan peran Pendidikan Agama Islam di Sekolah untuk mendidik peserta didik yang beriman, bertakwa, dan berakhlak mulia sesuai fitrahnya. Untuk menjawab keperluan tersebut, dilakukan penelitian library research yang menganalisis beberapa karya tulis yang relevan dengan pendekatan hermeneutik dan metode content analysis. Artikel ini menemukan bahwa optimalisasi Pendidikan Agama Islam dalam Penguatan Pendidikan Karakter di sekolah dapat dilakukan dengan: pertama, penguatan karakter guru muslim yang meneladani karakter Nabi SAW sebagai pendidik sejati; kedua, optimalisasi Pendidikan Agama Islam pada Penguatan Pendidikan Karakter berbasis kelas dengan paradigma ilmu berbasis tauhid, mengintegrasikan nilai-nilai keislaman dalam pembelajaran, dan penguatan materi Pendidikan Agama Islam di sekolah; ketiga, optimalisasi Pendidikan Agama Islam pada Penguatan Pendidikan Karakter berbasis sekolah dengan mengimplementasikan konsep pendidikan Islam berbasis takwa dan menjadikan surau sebagai labor karakter; dan keempat, optimalisasi Pendidikan Agama Islam pada Penguatan Pendidikan Karakter berbasis masyarakat dengan menyelenggarakan Islamic parenting serta kerjasama sekolah dengan orang tua dan masyarakat dalam penguatan karakter peserta didik.
\end{abstract}

Received : 09 Juli 2019; Revised: 09 Mei 2020; Accepted: 04 Juni 2020

(C) Tadris Jurnal Pendidikan Islam http://doi.org/10.19105/tjpi.

\section{Pendahuluan}

Pembangunan karakter bangsa telah menjadi salah satu prioritas sekaligus misi pembangunan nasional dalam Rencana Pembangunan Jangka Panjang Nasional (RPJPN) tahun 2005-2025. ${ }^{1}$ Implementasinya dalam pendidikan baru terwujud tahun 2010 era Pemerintahan Presiden Susilo Bambang Yudoyono (SBY) jilid II yang dikenal dengan kebijakan "Pendidikan Budaya dan Karakter Bangsa" (PBKB). PBKB muncul berdasarkan Instruksi Presiden Nomor 1 Tahun 2010 tentang Percepatan Pelaksanaan Prioritas Pembangunan Nasional Tahun 2010, yang menyebutkan bahwa salah satu program pendidikan adalah "Penguatan metodologi dan kurikulum" dengan tindakan penyempurnaan kurikulum dan metode pembelajaran aktif berdasarkan nilai-nilai budaya bangsa untuk membentuk daya saing dan karakter bangsa. PBKB dikembangkan melalui integrasi mata pelajaran, pengembangan diri, dan budaya sekolah. ${ }^{2}$.

Pada pemerintah Presiden Jokowi, dilakukan program penguatan, sehingga dikenal kebijakan "Penguatan Pendidikan Karakter", disingkat dengan PPK. Kebijakan ini perwujudan dari Nawacita butir ke delapan, yaitu memperkuat pendidikan karakter bangsa yang memunculkan Gerakan Nasional Revolusi Mental

\footnotetext{
1 Misi pertama dalam pembangunan nasional RPJP 2005-2025 adalah mewujudkan masyarakat berakhlak mulia, bermoral, beretika, berbudaya, dan beradab berdasarkan falsafah Pancasila adalah memperkuat jati diri dan karakter bangsa melalui pendidikan...'Undang-Undang Republik Indonesia Nomor 17 Tahun 2007 Tentang Rencana Pembangunan Jangka Panjang Nasional', 2025 2005. Hal.39 dan 78.

${ }^{2}$ Balitbang Puskur Kemdikbud, Pengembangan Pendidikan Budaya Dan Karakter Bangsa: Pedoman Sekolah (Jakarta: Puskur Kemdikbud, 2010). HIm.12.
} 
(GNRM). ${ }^{3}$ Sejak tahun 2016, melalui Kementerian Pendidikan dan Kebudayaan (Kemdikbud), dilakukan pembinaan beberapa sekolah untuk mengimplementasikan PPK. Pada tahun 2017, kebijakan ini diperkuat dengan ditetapkannya Peraturan Presiden RI Nomor 87 Tahun 2017 tentang Penguatan Pendidikan Karakter. Setahun kemudian, ditetapkan pula Peraturan Menteri Pendidikan dan Kebudayaan (Permendikbud) Nomor 20 Tahun 2018 tentang Penguatan Pendidikan Karakter pada Satuan Pendidikan Formal.

Alasan penting kenapa PPK dilaksanakan adalah karenanya adanya kecenderungan global berupa, pertama, berlangsungnya revolusi industri keempat yang ditandai dengan fenomena kemajuan teknologi informasi dan komunikasi dalam Era Revolusi Digital; kedua, perubahan peradaban masyarakat yang ditandai dengan berubahnya sendi-sendi kehidupan, kebudayaan, dan kemasyarakatan termasuk pendidikan; ketiga, semakin tegasnya abad kreatif yang menempatkan informasi pengetahuan, kreativitas, inovasi, dan jejaring sumber daya strategis bagi individu, masyarakat, korporasi negara. ${ }^{4}$

Di era revolusi industri 4.0., manusia dihadapkan pada kemajuan teknologi yang sedemikian cepat dan canggih yang menekankan pada pola digital economy, artificial intelligence, big data, robotic, dan lain sebagainya atau dikenal dengan fenomena disruptive innovation. Manusia dimanjakan dengan kecanggihan teknologi yang praktis, rasional, empiris, dan bersifat material. Satu sisi membawa banyak kebaikan manusia, namun di sisi lain berdampak negatif bagi kepribadian manusia. Sebut saja sikap individualis, materialis, hingga mengabaikan aspek spiritualitas dalam kehidupannya. Karena itu, pendidikan karakter memiliki peran strategis untuk dikembangkan agar peserta didik tetap memperoleh pendidikan sejati: memanusiakan manusia. Manusia itu tidak saja fisik, tapi esensinya terletak pada aspek ruhani. ${ }^{5}$ Akal, jiwa, dan kalbunya mesti menjadi orientasi pendidikan.

Di sisi lain, pendidikan Islam memiliki konsep yang lebih komprehensif dan universal. Persoalan berikutnya, umat Islam di Indonesia justru lebih banyak yang mengenyam pendidikan di sekolah umum dengan jumlah pelajaran agama yang relatif sedikit. Amat sulit mendidik generasi muslim yang taat jika hanya mengandalkan mata pelajaran agama 4 atau 3 jam tatap muka dalam seminggu. Karena itu, pendidikan karakter bisa menjadi media untuk mengoptimalisasikan peran strategis Pendidikan Agama Islam di Sekolah dalam membentuk peserta didik yang taat menjalankan agamanya.

Adapun rumusan masalah yang akan dikaji dalam artikel ini adalah bagaimanakah upaya mengoptimalkan Pendidikan Agama Islam (PAI) sebagai bagian penting dalam Penguatan Pendidikan Karakter (PPK) di Sekolah? Optimalisasi PAI tersebut akan dibatasi pada empat hal, yaitu penguatan karater guru muslim, PPK berbasis kelas, PPK berbasis sekolah, dan PPK berbasis masyarakat.

\section{Konsep Dasar Penguatan Pendidikan Karakter}

Peraturan Presiden RI Nomor 87 Tahun 2017 tentang Penguatan Pendidikan Karakter, pasal 1 menyebutkan bahwa "Penguatan Pendidikan Karakter yang selanjutnya disingkat PPK adalah gerakan pendidikan di bawah tanggung jawab satuan pendidikan untuk memperkuat karakter peserta didik melalui

\footnotetext{
3 Mohammad Ariandy, 'Kebijakan Kurikulum Dan Dinamika Penguatan Pendidikan Karakter Di Indonesia', Sukma: Jurnal Pendidikan 3, no. 2 (2019): 137-168.

${ }^{4}$ Sofie Dewayani, Panduan Praktis Implementasi Penguatan Pendidikan Karakter (PPK) Berbasis Kelas (Jakarta: Pusat Analisis dan Sinkronisasi Kebijakan, Kemdikbud, 2018). Hlm.1

5 Ema Yudiani, 'Komparasi Paradigma Psikologi Kontemporer Versus Psikologi Islam Tentang Manusia', Jurnal IImu Agama: Mengkaji Doktrin, Pemikiran, Dan Fenomena Agama 15, no. 1 (2014): 79-90.
} 
harmonisasi olah hati, olah rasa, olah pikir, dan olah raga dengan pelibatan dan kerja sama antara satuan pendidikan, keluarga, dan masyarakat sebagai bagian dari Gerakan Nasional Revolusi Mental (GNRM)."

Gerakan PPK menempatkan pendidikan karakter sebagai dimensi terdalam atau inti pendidikan nasional sehingga pendidikan karakter menjadi poros pelaksanaan pendidikan dasar dan menengah. ${ }^{6}$ Pada pasal 3 Perpres No. 87/2017 dijelaskan bahwa PPK dilaksanakan dengan menerapkan nilai-nilai Pancasila dalam pendidikan karakter terutama meliputi nilai-nilai religius, jujur, toleran, disiplin, bekerja keras, kreatit mandiri, demokratis, rasa ingin tahu, semangat kebangsaan, cinta tanah air, menghargai prestasi, komunikatif, cinta damai, gemar membaca, peduli lingkungan, peduli sosial, dan bertanggungiawab. Nilai-nilai tersebut merupakan perwujudan dari lima karakter utama yang saling berkaitan, religiositas, nasionalisme, kemandirian, gotong royong dan integritas. ${ }^{7}$

Permendikbud No. 20/2018, pasal 6 menjelaskan PPK pada sekolah dilaksanakan dengan tiga pendekatan berbasis kelas, sekolah, dan masyarakat.

1. PPK Berbasis Kelas, dilakukan dengan:

a. mengintegrasikan nilai-nilai karakter dalam proses pembelajaran secara tematik atau terintegrasi dalam mata pelajaran sesuai dengan isi kurikulum;

b. merencanakan pengelolaan kelas dan metode pembelajaran/ pembimbingan sesuai dengan karakter peserta didik;

c. melakukan evaluasi pembelajaran/pembimbingan; dan

d. mengembangkan kurikulum muatan lokal sesuai dengan kebutuhan dan karakteristik daerah, satuan pendidikan, dan peserta didik. ${ }^{8}$

2. PPK Berbasis Sekolah, dilaksanakan dengan cara:

a. menekankan pada pembiasaan nilai-nilai utama dalam keseharian sekolah;

b. memberikan keteladanan antar warga sekolah;

c. melibatkan seluruh pemangku kepentingan pendidikan di sekolah;

d. membangun dan mematuhi norma, peraturan, dan tradisi sekolah;

e. mengembangkan keunikan, keunggulan, dan daya saing sekolah sebagai ciri khas sekolah;

f. memberi ruang yang luas kepada peserta didik untuk mengembangkan potensi melalui kegiatan literasi; dan

g. mengembangkan minat, bakat, dan potensi melalui kegiatan ekstrakurikuler. ${ }^{9}$

3. PPK Berbasis Masyarakat diterapkan dengan upaya:

a. memperkuat peranan orang tua sebagai pemangku kepentingan utama pendidikan dan Komite Sekolah sebagai lembaga partisipasi masyarakat yang menjunjung tinggi prinsip gotong royong;

b. melibatkan dan memberdayakan potensi lingkungan sebagai sumber belajar seperti keberadaan dan dukungan pegiat seni dan budaya, tokoh masyarakat, alumni, dunia usaha, dan dunia industri; dan

c. mensinergikan implementasi PPK dengan berbagai program yang ada dalam lingkup akademisi, pegiat pendidikan, lembaga swadaya masyarakat, dan lembaga informasi. ${ }^{10}$

\footnotetext{
${ }^{6}$ Kemendikbud menyiapkan website ppk terkait dengan pedoman, praktik baik, dan informasi lainnya yang dapat diakses di alamat: cerdasberkarakter.kemendikbud.go.id.

${ }^{7}$ R. I. Kemdikbud, 'Konsep Dan Pedoman Penguatan Pendidikan Karakter Tingkat Sekolah Dasar Dan Sekolah Menengah Pertama', Jakarta: Kementrian Pendidikan Dan Kebudayan RI, 2016. HIm.8

8 Sofie Dewayani, Panduan Praktis Implementasi Penguatan Pendidikan Karakter (PPK) Berbasis Kelas.

9 Nadia Fernanda, Panduan Praktis Implementasi Penguatan Pendidikan Karakter (PPK) Berbasis Sekolah (Jakarta: Pusat Analisis dan Sinkronisasi Kebijakan, Kemdikbud, 2018). HIm. 5

${ }_{10}$ Indarti Suhadisiwi, Panduan Praktis Implementasi Penguatan Pendidikan Karakter (PPK) Berbasis
} 
Ketiga basis tersebut mesti bersinergi sehingga konsep tripusat pendidikan dapat diterapkan secara optimal, yaitu sekolah, keluarga dan masyarakat. Optimalisasi PPK di sekolah diselenggarakan melalui kegiatan intrakurikuler, kokurikuler, dan ekstrakurikuler secara kreatif dan terpadu. Optimalisasi di keluarga dilakukan melalui kegiatan bersama dan pelibatan keluarga di sekolah, rumah, dan lingkungan masyarakat. Sedangkan optimalisasi PPK di masyarakat dilaksanakan melalui pelibatan perorangan, kelompok masyarakat, dan/atau lembaga.

Khusus tentang pelibatan keluarga di sekolah, diatur pula dalam Permendikbud Nomor 30 Tahun 2017 tentang Pelibatan Keluarga pada Penyelenggaraan Pendidikan. Bentuk Pelibatan Keluarga pada sekolah dapat berupa:

a. menghadiri pertemuan yang diselenggarakan oleh Satuan Pendidikan;

b. mengikuti kelas Orang Tua/Wali;

c. menjadi narasumber dalam kegiatan di Satuan Pendidikan;

d. berperan aktif dalam kegiatan pentas kelas akhir tahun pembelajaran;

e. berpartisipasi dalam kegiatan kokurikuler, ekstra kurikuler, dan kegiatan lain untuk pengembangan diri Anak;

f. bersedia menjadi aggota Komite Sekolah;

g. berperan aktif dalam kegiatan yang diselenggarakan oleh Komite Sekolah;

h. menjadi anggota tim pencegahan kekerasan di Satuan Pendidikan;

i. berperan aktif dalam kegiatan pencegahan pornografi, pornoaksi, dan penyalahgunaan narkoba, psikotropika, dan zat adiktif lainnya (NAPZA); dan

j. memfasilitasi dan/atau berperan dalam kegiatan Penguatan Pendidikan Karakter Anak di Satuan Pendidikan. ${ }^{11}$

Pelaksanaan PPK di sekolah juga harus berlandaskan pada tiga prinsip dasar, yaitu: pertama, berorientasi pada berkembangnya potensi peserta didik secara menyeluruh dan terpadu; kedua, keteladanan dalam penerapan pendidikan karakter pada masing-masing lingkungan pendidikan; dan ketiga, berlangsung melalui pembiasaan dan sepanjang waktu dalam kehidupan sehari-hari (Pasal 3 Permendikbud 20/2018).

\section{Tantangan Pendidikan di Era Revolusi Industri 4.0.}

Istilah "Revolusi Industri" diperkenalkan oleh Friedrich Engels dan LouisAuguste Blanqui di pertengahan abad ke-19. Revolusi industri ini pun sedang berjalan dari masa ke masa. Fase pertama, industri 1.0. (1784) bertumpu pada penemuan mesin yang menitikberatkan (stressing) pada mekanisasi produksi yang digerakkan oleh tenaga air dan uap. Industri 2.0 (1870) dicirikan oleh produksi massal yang terintegrasi dengan quality control dan standarisasi yang dimungkinkan oleh pembagian kerja dan penggunaan energi listrik. Industri 3.0 (1969) ditandai dengan penyesuaian massal dan fleksibilitas manufaktur berbasis otomasi dan robot yang berdasarkan pada penggunaan elektronik dan teknologi informasi yang bertumpu pada integrasi komputerisasi. Sedangkan Industri 4.0 saat ini hadir menggantikan industri 3.0 yang ditandai dengan penggunaan sistem cyber fisik, digitalisasi dan otomatisasi perpaduan internet dengan manufaktur. ${ }^{12}$

Istilah revolusi industri 4.0 diterima secara meluas sejak Kanselir Jerman Angela Merkel menyorotinya di Hannover Fair 2011, yang membuat industri Jerman

\footnotetext{
Masyarakat (Jakarta: Pusat Analisis dan Sinkronisasi Kebijakan, Kemdikbud, 2018).

${ }_{11}$ Permendikbud, 'Pasal 6 No.30 Tahun 2013'

12 Suwardana Hendra, 'Revolusi Industri 4.0 Berbasis Revolusi Mental', Tuban: Universitas PGRI Ronggolawe, 2017. Muhammad Yahya, Era Industri 4.0: Tantangan dan Peluang Perkembangan Pendidikan Kejuruan Indonesia, Naskah Pidato Pengukuhan Penerimaan Jabatan Professor Tetap dalam Bidang IImu Pendidikan Kejuruan Fakultas Teknik Universitas Negeri Makassar, 14 Maret 2018; hlm. 2; lihat juga Pendidikan 4.0, Apa Itu? (https://eduaksi.com/pendidikan-4-0-apa/).
} 
sangat kompetitif. ${ }^{13} \mathrm{Hal}$ ini ditandai dengan berkembangnya teknologi internet dan semua perangkat berbasis komputer dapat terrsabung dalam jaringan bersama. Maka muncullah revolusi industri keempat "internet of things" yaitu jaringan raksasa yang sanggup menghubungkan semua perangkat dalam sebuah skema kerja bersamaan di seluruh dunia. ${ }^{14}$ Penggunaan robot dan sistem cyber fisik menggantikan tenaga manusia sehingga lebih murah, efektif, dan efisien. Karena itu, era 4.0 juga disebut dengan era disrupsi.

Revolusi industri 4.0 juga berdampak pada dunia pendidikan sehingga dikenal istilah pendidikan 4.0 (education 4.0) yang menggambarkan berbagai cara untuk mengintegrasikan teknologi cyber baik secara fisik maupun tidak ke dalam pembelajaran. ${ }^{15}$ Pendidikan 4.0 merupakan fenomena yang merespons kebutuhan revolusi industri 4.0 di mana manusia dan mesin berinteraksi sekaligus diselaraskan untuk memperoleh solusi, bahkan inovasi baru. ${ }^{16}$ Pembelajaran dituntut mampu beradaptasi dengan perkembangan era 4.0 di mana pendidik dan peserta didik mampu mengelola dan memanfaatkan data information technology (IT), operational technology (OT), internet of things (ToT), dan big data analitic, lalu mengintegrasikannya dengan objek fisik, digital, dan manusia. Harapannya, dihasilkan lulusan yang kompetitif dan terampil dalam aspek data literacy, technological literacy, dan human literacy. ${ }^{17}$ Dengan demikian, revolusi industri 4.0 menuntut pengelolaan pendidikan berbasis IT yang berdampak ada efektivitas pembelajaran dengan mutu yang terjamin. Pembelajaran mesti menyenangkan dan mengaktifkan.

Namun dalam konteks pedidikan Islam, revolusi industri 4.0. Era 4.0 menimbulkan sejumlah peluang terhadap pengembangan pendidikan Islam. Muhammad Kosim menulis, di antara peluang tersebut adalah:

1. Mempermudah akses penyebaran dan pengembangan pendidikan Islam. Kecanggihan teknologi di era 4.0, bisa dimanfaatkan untuk mengembangkan pendidikan Islam. Ajaran Islam tidak lagi dipelajari dari rumah ke rumah, atau di perpustakaan buku. Namun ajaran Islam bisa disajikan melalui dunia maya.

2. Menambah pekerjaan baru. Dalam konteks pendidikan Islam, muncul beberapa peluang kerja, seperti mendesain pembelajaran PAI berbasis online, mendidik di dunia maya, menyusun dan menciptakan sumber belajar pendidikan Islam secara elektrik, dan sebagainya.

3. Perkembangan lembaga pendidikan Islam di Indonesia yang kian pesat membutuhkan sentuhan teknologi. Lembaga Pendidikan Islam formal (seperti RA, Madrasah Ibtidaiyah, Tsanawiyah, Aliyah, dan Perguruan Tinggi Keagamaan Islam) dan nonformal (pendidikan diniyah: pendidikan Alquran dan madrasah diniyah, pesantren; serta majlis taklim) yang demikian menjamur tidak boleh terasing dan tersingkir dari pendidikan 4.0.

\footnotetext{
${ }^{13}$ Termonologi 4.0 semakin dikenal ketika dijadikan tema utama pertemuan tahunan WEF (Word Economic Forum) di Davos, Swiss tahun 2016; Mastering the Fourth Industrial Revolution. Lee et al (2013), seperti dikutip Muhammad Yahya, menjelaskan bahwa industri 4.0 ditandai dengan peningkatan digitalisasi manufaktur yang didorong oleh empat faktor, yaitu: pertama, peningkatan volume data, kekuatan komputasi, dan konektivitas; kedua, munculnya analisis, kemampuan, dan kecerdasan bisnis; ketiga, terjadinya bentuk interaksi baru antara manusia dengan mesin; dan keempat, perbaikan instruksi transfer digital ke dunia fisik, seperti robotika dan 3D printing. Ratna Wardani, '21st Century Educator: Menyongsong Transformasi Pendidikan 4.0', in Porsiding Seminar Nasional Dinamika Informatika Senadi. Yogyakarta: Universitas PGRI Yogyakarta, 2018. HIm.4.

${ }^{14}$ Amir Hamzah, 'Etos Kerja Guru Era Industri 4.0', Literasi Nusantara, 2019. HIm.8

15 Sigit Priatmoko, 'Memperkuat Eksistensi Pendidikan Islam Di Era 4.0', TA'LIM: Jurnal Studi Pendidikan Islam 1, no. 2 (2018): 221-239.

16 Muhamad Imaduddin, Membuat Kelas Online Berbasis Android Dengan Google Classroom: Terobosan Pembelajaran Era Revolusi Industri 4.0 (Garudhawaca, 2018).

17 Imaduddin.
} 
4. Kebutuhan dimensi ruhani. Era 4.0 selalu berbicara tentang kecanggihan teknologi yang sesungguhnya bersifat materi dan memberi kemudahan bagi aktivitas manusia secara jasmani. Tanpa kesucian ruhani, kecanggihan teknologi lebih mengundang malapetaka daripada kemaslahatan umat. ${ }^{18}$

Di samping beberapa peluang yang ada, terdapat sejumlah tantangan pendidikan Islam di era 4.0, di antaranya:

1. Kecenderungan generasi $Z$ yang lebih terbuka dan rasional. Bagi mereka yang memiliki keinginan untuk belajar agama dan hanya "berguru" kepada google, facebook atau media online lainnya tanpa bimbingan guru yang berstatus sebagai ulama, dapat menyesatkan paham beragamanya.

2. Dampak negatif internet. Jaringan internet yang masuk dalam rumah, kamar, bahkan saku setiap anak dapat merusak karakter mereka, seperti pornografi, paham anti-agama, ujaran kebencian, fitnah, dan sebagainya.

3. Paham ekstrim kanan dan kiri. Akses informasi yang sangat terbuka dan cepat menyebabkan berbagai aliran dan paham keagamaan semakin beragam. Paham ekstrim kanan cenderung berpikir tekstual, fanatik, hingga menjadi radikal. Sebaliknya, ekstrim kiri mengedepankan rasional, kontekstual, menggugat nash, lalu menjadi liberal.

Tantangan dikotomi ilmu. Paradigma ilmu yang berkembang di Barat bersifat dikotomis. Revolusi industri 4.0 tidak terlepas dari peran Barat dalam mengembangkan ilmu pengetahuan dan teknologi. Sementara epistemologi keilmuan yang berkembang di Barat menekankan pada pendekatan rasional, empiris, dan dikotomik. Hal ini dapat memicu lahirnya ilmuan yang sekular dan dikotomis. ${ }^{19}$

\section{METODE}

Penelitian ini menggunakan jenis penelitian library research yakni penelitian yang dilakukan melalui pengumpulan data atau karya tulis IImiah yang bertujuan untuk memecahkan suatu masalah. Pada dasarnya penelitian kepustakaan itu termasuk kategori penelitian kualitatif, karena terdapatnya kepentingan terhadap penafsiran dan mencari makna dari teks-teks tertulis. ${ }^{20}$ Penelitian kepustakaan mengarahkan penelitiannya pada pengkajian dan penelusuran ide-ide dan khasanah pemikiran pada sumber-sumber kepustakaan seperti naskah-naskah, karya tulis dan lain sebagainya. ${ }^{21}$ Jadi, untuk meneliti konsep Penguatan Pendidikan Karakter melalui Pendidikan Agama Islam dalam menjawab tantangan era revolusi 4.0 ini dianalisis dengan menggunakan sumber tertulis dari karya tulis yang relevan.

Dalam memahami dan menafsirkan serta memaknai literatur dan teks, digunakan pendekatan hermeneutik. Urgensi pendekatan hermeneutik dalam penelitian adalah sebagai upaya memahami makna teks (kitab suci, buku, undangundang dan lainnya) yang berfungsi untuk menghindari agar tidak terjadi distorsi pesan atau informasi antara penulis teks dan pembaca teks. ${ }^{22}$

\footnotetext{
18 Muhammad Kosim, 'Pendidikan Islam Di Era Revolusi Industri 4.0; Mempertegas Kesiapan Mahasiswa PAI Menjadi Pendidik Sejati, Makalah Seminar Seminar Nasional Forum Silaturahmi Mahasiswa (Forsima) PAI Se-Indonesia, Kamis, 20 Desember 2018 Di Gedung Serba Guna UIN Imam Bonjol Padang', n.d.

${ }^{19}$ Muhammad Kosim.

20 Suyanto Bagong, 'Metode Penelitian Sosial: Berbagai Alternatif Pendekatan, Jakarta: Kencana', 2005. Cet.1, hlm. 186

${ }_{21}$ Sutrisno Hadi, Metodologi Research, (Yokyakarta: Rake Sarasin,tt), hlm.19

22 Imam Suprayogo and Tobroni, Metodologi Penelitian Sosial-Agama (Remaja Rosdakarya, 2001). HIm.73-75
} 
Di dalam pengolahan dan penganalisaan semua data dari literatur serta teks, digunakan metode content analysis. ${ }^{23}$ Metode content analysis di dalam mengukur tingkat akurasi dan proses penarikan kesimpulan terhadap pesan, setidaknya memiliki tiga langkah yang dapat dilakukan, yaitu deskriptif, analisis isi secara kritis, dan korelatif. ${ }^{24}$ Secara umum, proses pengolahan data dalam sebuah penelitian dapat juga dikelompokkan kepada tiga tahapan yang meliputi: pertama, aktivitas pengumpulan data dari referensi-referensi kajian ilmiah yang kemudian mengelompokkannya dan mendeskripsikannya; kedua, kegiatan analisis data setelah mendeskripsikan konsep-konsep pemikiran, dan ide-ide, kemudian dianalisis dengan menggunakan pisau analisis pola berfikir analitik induktif, deduktif, dan interaktif (paduan dari induktif dengan deduktif); dan ketiga memberikan penafsiran dan pemaknaan terhadap hasil analisis yang bertujuan untuk mengambil kesimpulan-kesimpulan. Dari kesimpulan interpretatif ini dibangun gagasan dan ideide tentang objek penelitian.

\section{Pembahasan}

Konsep pelaksanaan PPK yang diuraikan di atas telah diuraikan dengan teknis sehingga dapat diterapkan di sekolah-sekolah. Namun terdapat sejumlah masalah dalam pelaksanaan PPK di sekolah di antaranya: Pertama, belum optimalnya keinginan dan komitmen pihak sekolah untuk menerapkan PPK secara komprehensif. Akibatnya, PPK sekedar program di atas kertas tanpa hasil yang menggembirakan.

Kedua, program PPK lebih banyak diarahkan pada pembinaan peserta didik, sementara penguatan karakter guru kurang diperhatikan. Padahal guru adalah kunci utama PPK. Pembinaan guru selama ini lebih menekankan pada kompetensi pedagogik dan profesional, sementara kompetensi personal dan sosial sering kali dianggap sudah mapan dan tak perlu mendapat pembinaan intensif. Sejatinya PPK mesti diterapkan oleh guru yang berkualitas dengan keteladanan sebagai syarat mutlak dan didukung kreativitas dan inovasi guru dalam pembelajaran serta kepeduliannya dalam kegiatan PPK di sekolah.

Ketiga, PPK masih menekankan pada praktik pembiasaan baik dan lebih menyentuh aspek fisik dan tampilan. Meskipun ada penegasan bahwa PPK didasarkan pada olah raga, olah rasa, olah pikir, dan olah hati, namun belum menyentuh esensi manusia. Manusia adalah makhluk Tuhan yang memiliki aspek ruhaniah sebagai esensi manusia itu sendiri. Pendidikan seharusnya mengoptimalkan potensi fitrah yang bersifat hanif sehingga pendidikan ruhani (tarbiyah ruhiyah) menjadi inti dalam PPK.

Keempat, rendahnya manajerial kepala sekolah sangat berdampak terhadap implementasi PPK di sekolah. Kasus jual beli jabatan, praktik pungli di sekolah, hingga pengangkatan kepala sekolah yang tidak berdasarkan pada profesionalisme pasti berdampak pada implementasi PPK, karena sekolah diurus oleh pimpinan yang tidak memiliki niat baik.

Kelima, nilai-nilai karakter yang dikembangkan belum tegas menjadikan nilai relegius sebagai basis utama. Lima nilai karakter utama masih disejajarkan antara religius, nasionalis, mandiri, gotong royong, dan integritas. ${ }^{25}$ Seharusnya, lima karakter utama yang dijiwai dari Pancasila itu sesuaikan dengan perisai yang

\footnotetext{
${ }^{23}$ Suprayogo and Tobroni.

24 Metode analisis ini pada awalnya berkembang dalam lapangan informasi yang hertujuan untuk mengolah data atau pesan dalam menarik sebuah kesimpulan, termasuk juga dalam hal ini penilaian terhadap pesan dan sumber pesan. Lihat Klaus Krippendorff, 'Analisis Isi: Pengantar Teori Dan Metodologi, Terj', Farid Wajidi. Jakarta: Rajawali Pers, 1991.

${ }^{25}$ Hendarman, dkk (Tim Penyusun), Konsep Dan Pedoman Penguatan Pendidikan Karakter Tingkat Sekolah Dasar Dan Menengah (Jakarta: Tim PPK Kemdikbud, 2016).
} 
melekat di dada garuda di mana Sila pertama Ketuhanan Yang Maha Esa dengan gambar Bintang berada di tengah, menyentuh, mendasari, dan mengikat empat lambang sila lainnya. ${ }^{26}$ Tegasnya, nilai religius idealnya menjadi poros utama sebagai dasar, landasan, dan pondasi nilai karakter nasionalis, mandiri, gotong royong, dan integritas.

Pendidikan Islam menjadi solusi atas problematika di atas. Program PPK dijadikan sebagai acuan teknis dalam menerapkan pendidikan Islam di sekolah. Artinya, program PPK mesti diisi dengan konsep dan prinsip Pendidikan Islam sehingga sekolah mampu melahirkan lulusan yang beriman, bertakwa, dan berakhlak mulia sebagaiamana yang diinginkan oleh tujuan Sistem Pendidikan Nasional.

Islam mengandung ajaran ideal untuk membentuk akhlak manusia. Pendidikan karakter sesungguhnya akan mudah terbentuk jika pendidikan menerapkan ajaran Islam. Karena itu, Pendidikan Agama Islam (PAI) memiliki peran strategi dalam mendidik karakter peserta didik.

Hanya saja, PAl di sekolah berperan sebagai mata pelajaran. Jika PAl hanya berperan sebagai mata pelajaran lalu diajarkan oleh guru agama secara parsial, maka konsep pendidikan Islam tidak akan efektif dalam mendidik karakter peserta didik.

Sejatinya, konsep pendidikan Islam dapat dikembangkan di sekolah. Sebab indikator utama dari tujuan pendidikan nasional adalah membentuk manusia yang beriman, bertakwa dan berakhlak mulia. Mustahil tujuan itu tercapai tanpa peran agama. Maka sekolah yang memiliki guru dan siswa yang beragama Islam, idealnya menerapkan konsep pendidikan Islam secara utuh.

Dalam konteks pelaksanaan PPK di sekolah, konsep pendidikan Islam harus diterapkan dalam penguatan pendidikan karakter guru muslim, serta optimalisasi PAI pada PPK berbasis kelas, sekolah, dan masyarakat.

\section{A. Penguatan Karakter Guru Muslim}

Dapatkah peran guru digantikan oleh teknologi informasi yang berkembang di era 4.0? Bukankah internet memiliki big data yang akurat, cepat dan luas memberi jawaban atas berbagai kebutuhan ilmu pengetahuan? Ya, jika pendidikan hanya dipahami sebagai proses transfer of knowladge, maka media internet seperti pemanfaatan google dan youtube seringkali lebih "pintar" dari guru dalam menampilkan sejumlah informasi tentang ilmu pengetahuan. Hanya saja, guru bukan hanya mesin otak. Sosok pendidik sejati dituntut mampu mencerdaskan akal, hati, dan fisik manusia secara komprehensif. Teknologi tidak bisa menggantikan sentuhan ruhani guru. ${ }^{27}$

Era revolusi industri 4.0, yang paling dibutuhkan dari guru adalah keteladanannya. Sumber teladan terbaik adalah Nabi Muhammad SAW. Maka penguatan karakter guru muslim, terlepas dia guru mata pelajaran PAI atau tidak, mesti dilakukan dengan mempersiapkan mereka meneladani Nabi Muhammad SAW dalam menjalankan perannya sebagai guru.

Tugas-tugas nabi sebagai pendidik yang seharusnya dilakukan oleh guru dapat dilihat dalam surat al-Baqarah/2 ayat 151. Paling tidak ada lima tugas Nabi SAW sebagai guru sejati yang seharusnya dipedomani dan dikembangkan oleh guru hari ini. ${ }^{28}$ Pertama, tilawah, yaitu mengajar dengan membacakan ayat-ayat

\footnotetext{
${ }^{26}$ Ahmad Tafsir, IImu Pendidikan Dalam Perspektif Islam (Bandung Remaja Rosdakarya, 2008, Cet (Ke, n.d.). hlm.84

27 Muhammad Kosim.

${ }^{28}$ Lima tugas Nabi SAW yang perlu diimplementasikan oleh guru ini, telah ditulis dan dipublis pada tahun 2017 di Koran dalam bentuk tulisan opini. Muhammad Kosim, 'Menjadi Guru Sejati' (Koran Padang Ekspres, 25 November 2017).
} 
Allah. ${ }^{29}$ Membaca ayat-ayat Allah, baik yang tertulis dalam Alquran maupun dengan mengamati fenomena alam sebagai ayat-Nya, ${ }^{30}$ penting dilakukan sehingga memiliki keyakinan bahwa semua ciptaan Allah memiliki keteraturan yang bersumber dari Allah serta memandang tak satu pun ciptaan-Nya yang sia-sia. Hal ini relevan dengan kebijakan pemerintah dewasa ini dengan "Gerakan Literasi Sekolah". Guru dituntut untuk menjadi sosok literal dan mampu memotivasi peserta didik untuk gemar membaca. Meski guru menjadi sumber belajar, tetapi guru tak boleh berhenti membaca, menelaah, dan melakukan penelitian sederhana sehingga dalam menjalankan tugas ia tampil profesional. Aktivitas membaca harus didasari oleh tauhid, seperti yang tersirat dalam wahyu pertama diterima Nabi SAW: Bacalah dengan menyebut nama Tuhanmu yang menciptakan. Dalam konteks ini, guru harus membaca agar semakin dekat dengan Sang Pencipta.

Kedua, tazkiyah, yaitu menyucikan. Rasulullah SAW telah berhasil menyucikan jiwa umatnya dari segala bentuk kemusyrikan dan kemaksiatan. ${ }^{31} \mathrm{Hal}$ ini bisa dilakukan karena Nabi SAW sendiri memiliki jiwa yang bersih, akhlak yang mulia (Qs. Qalam ayat 4). Dalam konteks ini, guru harus berupaya senantiasa menyucikan jiwanya. Sebab, guru yang berjiwa kotor tidak akan mampu menyucikan jiwa peserta didiknya. Inilah kunci pembentukan karakter yang kini lagi dikembangkan oleh pemerintahan Jokowi-JK. Penguatan Pendidikan Karakter (PPK) pasti gagal jika guru hadir tanpa karakter. Sebaliknya, PPK niscaya berhasil di tangan guru yang memiliki kebeningan hati, jiwa yang suci dan perilaku yang berbudi. Oleh karena itu, guru harus melatih diri agar memiliki kecerdasan ruhaniah terlebih dahulu. ${ }^{32}$ Inilah modal utama setiap guru sehingga tetap dibutuhkan di era 4.0. Teknologi informasi yang sangat canggih tidak bisa menggantikan ruhaniah guru. Said Hawwa, yang menyebut da tiga pilar pendidikan ruhani, yaitu ilmu pengetahuan, latihan-latihan ruhani, dan wirid harian. ${ }^{33}$ Ketiganya merupakan upaya yang dapat dilakukan untuk mencerdaskan ruhaniah seseorang, baik pribadi guru maupun pada peserta didiknya.

Ketiga, ta'lim al-kitab, yaitu mengajarkan kitab, Alquran. Inilah mukjizat terbesar Nabi SAW. Dengan Alquran, Allah menuntun manusia untuk memperoleh hidayah-Nya sehingga benih-benih kasih sayang tumbuh mekar dalam dada setiap mukmin. Umat pun tampil membawa rahmat bagi segenap alam. Guru sejati juga bertugas mengajarkan pesan Alquran kepada peserta didiknya. Apa pun mata pelajaran yang diampu oleh guru, hendaklah diintegrasikan dengan ayat-ayat Allah SWT. Hal ini relevan dengan kurikulum 2013 yang memperhatikan sikap spiritual pada Kompetensi Inti satu (KI 1). Sikap spiritual peserta didik akan mudah terbentuk melalui pendidikan agama. Sementara dasar utama ajaran agama Islam adalah Alquran. Maka ilmu yang diajarkan oleh setiap guru hendaknya terkait dengan pesan-pesan mulia Alquran.

Dalam hal ini, guru yang beragama Islam dapat bekerja sama dengan guru PAI untuk merumuskan pola pembelajaran terintegrasi dengan ayat-ayat atau pesan-pesan Alquran. Begitu pula gerakan literasi di sekolah dapat dikembangkan dengan melakukan kajian terhadap ayat-ayat Alquran, sebab negeri ini akan berjaya jika rakyatnya dekat dengan kitab sucinya.

\footnotetext{
${ }^{29}$ Abu Ja'far Muhammad bin Jarir, 'Ath-Thabari', Jami'al-Bayan at-Ta'wil Al-Qur'an, 2008.

${ }^{30}$ M. Quraish Shihab, 'Tafsir Al-Misbah', Jakarta: Lentera Hati 2 (2002). HIm.129

${ }^{31}$ Al-Imam Muhammad bin Ali bin Muhammad Asy-Syaukani, Tafsir Fathul Qadir, Terj. Amir Hamzah Fachruddin (Jakarta: Pustaka Azzam, 2011), Jilid 1. HIm.563.

${ }_{32}$ Muhammad Kosim, 'Pendidikan Karakter Berbasis Keislaman Dan Keindonesiaan', Jurnal Al-Taujih: Bingkai Bimbingan Dan Konseling Islami 3, no. 2 (2017): 94-106.

${ }^{33}$ Sa'id Hawwa, 'Tarbiyatuna Ar-Ruhiyah, Penj', Imam Fajaruddin, Surakarta: Era Adicitra Intermedia, 2010.hlm.169-175
} 
Keempat, ta'lim al-hikmah, yaitu mengajarkan hikmah. Dalam tafsir Ibn Katsir, hikmah berarti Sunnah. ${ }^{34}$ Rasulullah SAW mengajar manusia dengan ucapan dan tindakannya yang sesuai dengan Alquran. Itulah hadis yang juga menjadi pegangan hidup manusia. Quraish Shihab, selain mengartikan hikmah sebagai sunnah, juga bermakna kebijakan dan kemahiran melaksanakan hal yang mendatangkan manfaat serta menampik mudharat. ${ }^{35}$ Dengan kata lain, hikmah memadukan antara ilmu dan amal yang mendatangkan kebaikan.

Guru berkarakter muslim juga mengajar peserta didiknya dengan hikmah. Ini bermakna bahwa guru harus meneladani perilaku Nabi SAW dengan mempedomani sunnahnya. Guru juga mesti memiliki integritas kepribadian; satu antara perkataan, pemikiran dan perbuatan. Perilaku guru harus selaras dengan keilmuan yang dimilikinya. Jadilah guru teladan sehingga peserta didik memiliki panutan dalam memperoleh hikmah.

Dalam surat Qs. al-Baqarah/2: 269 dijelaskan bahwa hikmah diberikan Allah kepada siapa saja yang dikehendaki-Nya. Mereka termasuk dalam kategori ulul albab. Adapun karakter ulul albab adalah mereka yang senantiasa berzikir dan berpikir (Qs. Ali Imran/3: 190-191). Maka di antara upaya guru mendidik peserta didiknya dengan hikmah adalah dengan melatih zikir dan pikir.

Kelima, ta'lim ma lam takunu ta'lamun, yaitu mengajarkan apa-apa yang belum kamu ketahui. Nabi SAW adalah pendidik sejati yang mengajarkan berbagai ilmu pengetahuan kepada umatnya berdasarkan tuntunan wahyu yang ia terima. Sebelumnya masyarakat jahiliyah tenggelam dalam kedunguan akidah, tertutupnya hati nurani dan menjadi pemuja kemewahan dunia. Lalu Nabi SAW mendidik manusia untuk mengetahui hakikat diri dan pencipta-Nya. Umat manusia pun mengenal Allah dan memahami cara mengabdikan diri pada-Nya.

Guru berkarakter penuh dengan kreasi dan inovasi. la dapat mengajarkan sesuatu yang benar-benar asing, belum diketahui oleh peserta didiknya. Hal ini memicu inovasi, penemuan-penemuan produk teknologi, atau konsep-konsep baru yang bermanfaat, mempermudah dan membantu kehidupan manusia sehari-hari, sesuai dengan tuntutan era revolusi industri 4.0.

\section{B. Optimalisasi PAI pada PPK Berbasis Kelas}

Pendidikan Agama Islam memiliki peran penting dalam memperkaya implementasi PPK berbasis kelas. Paling tidak ada tiga hal yang dapat dilakukan, yaitu:

1. Paradigma ilmu berbasis tauhid

Pada hakikatnya, ayat-ayat Allah terdiri dari ayat-ayat naqliyah dan kauniyah. Materi dasar PAI banyak bersumber dari ayat-ayat naqliyah. Sedangkan materi sains dan teknologi bersumber dari ayat-ayat kauniyah. Namun semua ilmu itu pada hakikatnya berasal dari Allah Swt. ${ }^{36}$ Maka setiap guru muslim harus memiliki paradigma bahwa setiap ilmu yang ia ajarkan berasal dari Allah sehingga ilmu itu tidak sekedar dipahami dan dipraktikkan tetapi dipertanggungjawabkan kepada Allah Swt. Semakin tinggi ilmu seseorang, sejatinya semakin tunduk dan takut kepada Allah Swt. Itulah tugas guru yang paling mulia, yaitu sebagai ulama (Qs. Fathir/35: 28).

Inilah yang disebut dengan ilmu berbasis tauhid. Tauhid menjadi titik sentral pendidikan karakter Islami. Tanpa tauhid, keilmuan seseorang akan mendatangkan

\footnotetext{
${ }^{34}$ Al-Imam Abul Fida Isma'il Ibnu Kasir Ad-Dimasyqi, Tafsir Ibn Katsir, Penj. Bahrum Abu Bakar, Jilid 2 (Bandung: Sinar Baru Algensindo, 2000). hlm.42.

${ }^{35}$ Shihab, 'Tafsir Al-Misbah'. hlm. 327.

${ }^{36}$ Roikhan Mochamad Aziz, 'Teori H Sebagai Ilmu Wahyu Dan Turats Dalam Islam', 2016. hlm.104.
} 
malapetaka. ${ }^{37}$ Jika setiap guru muslim memahami konsep ilmu dalam Islam, maka dalam pembelajaran ia akan berupaya menanamkan nilai-nilai tauhid. Setiap ilmu yang diajarkan akan meningkatkan keimanan pada Allah SWT. Itulah salah satu ciri mukmin sejati: wa idza tuliyat alaihim ayaatuhu zaadathum imaana, dan apabila dibacakan (diajarkan) ayat-ayat Allah maka bertambahlah imannya (Qs. al-Anfal/8: 2).

2. Integrasi ayat-ayat Alquran, hadis dan nilai-nilai Islam dalam pembelajaran sesuai materi yang relevan

Jika guru telah memiliki paradigma ilmu berbasis tauhid, maka guru dapat mengintegrasikan ayat-ayat Alquran, hadis dan nilai-nilai ajaran Islam dengan materi yang relevan dalam pembelajarannya. Hal ini telah dilakukan oleh guru mata pelajaran umum di SMA/SMK se Sumatera Barat sejak tahun 2017 dalam program "Integrasi Pendidikan Alquran dan Budaya Alam Minangkabau dalam Mata Pelajaran Umum". ${ }^{38}$ Hanya saja tidak semua guru umum memiliki kemampuan untuk mengintegrasikan ayat-ayat Alquran, hadis dan nilai-nilai ajaran Islam dalam pembelajarannya. Di sinilah peran penting guru PAI di sekolah untuk berkolaborasi dengan guru umum sehingga integrasi ilmu dapat dilakukan secara efektif. Upaya ini juga relevan dengan kurikulum 2013 yang menakankan pada sikap spiritual (KI1). Diharapkan, dengan upaya seperti ini, lahir karakter peserta didik yang berintegritas sebagai ilmuan yang ulama, atau ulama yang ilmiah. Jika tidak, dikhawatirkan akan lahir ilmuan yang sekuler, memisahkan antara ilmu dengan agama, atau malah mencurigai dan memusuhi eksistensi agama. Dalam istilah Syed Muhammad Naquib al-Attas, perlu melakukan Islamisasi IImu, yaitu pembebasan ilmu pengetahuan dari penafsiran-penafsiran yang didasarkan pada ideologi sekuler, dan dari makna-makna serta ungkapan-ungkapan manusiamanusia sekuler. ${ }^{39}$

\section{Penguatan Pendidikan Agama Islam di Sekolah}

Materi PAI di sekolah relatif sedikit, hanya 4 jam pelajaran untuk SD, dan 3 jam di SMP dan SMA/SMK. Padahal materi PAI itu sangat luas, ada aspek akidah, alquran, hadis, akhlak, figh, dan sejarah Islam. Jika pemahaman agama peserta didik lemah, akan membahayakan sikap keberagamaan mereka, bisa menjadi radikal, liberal, atau malah ateis. Jika hal itu terjadi, maka pendidikan karakter yang menginginkan lahirnya insan yang bertakwa (religius) niscaya gagal total.

Karena itu, sekolah perlu memperkuat materi PAI dalam pembelajaran. Hal itu bisa dilakukan dengan cara pendalaman materi, atau menambah jumlah jam belajar. ${ }^{40} \mathrm{Hal}$ ini diakomodir Peraturan Pemerintah (PP) Nomor 55 Tahun 2007

\footnotetext{
37 Muhammad Kosim, 'Pendidikan Karakter Islami: Mempertegas Identitas Kader HMI' (Tarbiyah UIN Imam Bonjol Padang, 2018).

${ }^{38}$ Dinas Pendidikan Provinsi Sumatera Barat, 'Pedoman Pengintegrasian Pendidikan Alquran Dan Budaya Alam Minangkabau Pada Mata Pelajaran Umum Sekolah Menengah Atas (SMA)' (Dinas Pendidikan Provinsi Sumatera Barat, 2017).

${ }^{39}$ Syed M. Naquib al-Attas, Konsep Pendidikan Dalam Islam (Bandung: Mizan, 1988) cet. ke-3, hlm. 90. Al-Attas menawarkan dua tahapan islamisasi ilmu pengetahuan. Pertama, mengasingkan unsurunsur atau konsep-konsep kunci dari suatu ilmu yang mengandung watak, kepribadian, kebudayaan dan peradaban Barat dan dibentuk dalam cetakan budaya Barat yang tidak sesuai dengan Islam. Kedua, setelah proses pengasingan itu, ilmu yang telah terbebaskan tersebut diisi dengan unsur-unsur dan konsep kunci Islam yang sesuai dengan fitrah. Syeh Muhammad Naquib al-Attas, Islam dan Sekularisme, Penj. Khalif Muammar, (Bandung: Institut Pemikiran Islam dan Pembangunan Insan [PIMPIN], 2011), cet. ke-2, hlm. 200-202.

${ }^{40}$ Muslih Muslih and Miftachul Ulum, 'PENDIDIKAN ISLAM ANTARA DUA ATAP: STUDI PADA KEBIJAKAN PENDIDIKAN ISLAM DI SEKOLAH DAN MADRASAH', Mudir: Jurnal Manajemen Pendidikan 1, no. 2 (2019): 48-65.
} 
tentang Pendidikan Agama dan Keagamaan, pasal 5, ayat (8): Satuan pendidikan dapat menambah muatan pendidikan agama sesuai kebutuhan. Lalu ayat (9) Muatan sebagaimana dimaksud pada ayat (8) dapat berupa tambahan materi, jam pelajaran, dan kedalaman materi. Aturan ini juga ditindaklanjuti dengan Peraturan Menteri Agama (PMA) Nomor 16 Tahun 2010 tentang Pengelolaan Pendidikan Agama di Sekolah.

Sayangnya, PP tersebut tidak memiliki turunan berupa Permendiknas atau Permendikbud. Padahal sekolah lebih "taat" pada Menteri Pendidikan dari pada Menteri Agama. Apalagi struktur kurikulum yang diterapkan oleh sekolah mesti terintegrasi dengan sistem Dapodik (Daftar Pokok Pendidikan), sehingga amanat PP tersebut sulit dilakukan. Akibatnya, aturan yang telah memberi peluang lebar itu tertutup karena tidak diikuti oleh kebijakan yang lebih teknis. Jika pendidikan agama lebih diperkuat, jelas menjadi modal utama untuk mendidik karakter peserta didik. Meski begitu, selagi PP tersebut belum dicabut masih ada harapan jika saja para pengelola negeri ini menyadari pentingnya pendidikan agama di sekolah.

\section{Optimalisasi PAl pada PPK Berbasis Sekolah}

Pendidikan Agama Islam juga berperan mengoptimalkan implementasi PPK berbasis sekolah. PAI berperan penting dalam membangun kultur religius (religious culture) di sekolah. Paling tidak ada dua hal yang perlu dilakukan.

1. Implementasi Pendidikan Islam Berbasis Takwa

Takwa merupakan salah satu indikator utama dari tujuan sistem pendidikan nasional. Idealnya, peserta didik yang beragama Islam mesti memahami konsep takwa dan berupaya untuk meraihnya sehingga mereka menjadi muttaqin. PPK berbasis sekolah yang menekankan pentingnya pengkondisian lingkungan sekolah untuk mendukung penanaman nilai-nilai karakter, dapat mengoptimalkan upaya meraih posisi takwa.

M. Ashaf Shaleh menemukan beberapa ayat Al Quran yang mengandung kata la'allakum tattaqun (agar kamu bertakwa) dan la'allahum yattaqun (agar mereka bertakwa). Dari ayat-ayat ini, ia simpulkan delapan upaya untuk membentuk sikap takwa, yaitu:

a. mengkaji Al Quran (Qs. Thaha/20: 113 dan al-Zumar/39: 27-28).

b. berpegang teguh dan melaksanakan is kandungan Al Quran (Qs. Al-Araf/7: 171 dan al-Baqarah/2: 63).

c. mengesakan Allah (Qs. al-An'am/6: 51).

d. mengingat perintah Allah (Qs. al-An'am/6: 69).

e. istiqamah di jalan Islam (Qs. al-An'am/6: 153).

f. beribadah kepada Allah (Qs. al-Baqarah/2: 21).

g. melaksanakan puasa (Qs. al-Baqarah/2: 183).

h. melaksanakan qishash (Qs. al-Baqarah/2: 179). ${ }^{41}$

Berdasarkan delapan upaya tersebut, perlu mendesain kegiatan di sekolah yang dapat membentuk karakter peserta didik agar menjadi orang yang bertakwa. Contoh kegiatan yang dapat dilakukan adalah seperti pada tabel berikut ini. 41 HM Ashaf Shaleh, Takwa: Makna Dan Hikmahnya Dalam al-Qur'an (Penerbit Erlangga,
2002)hlm.25-41. 


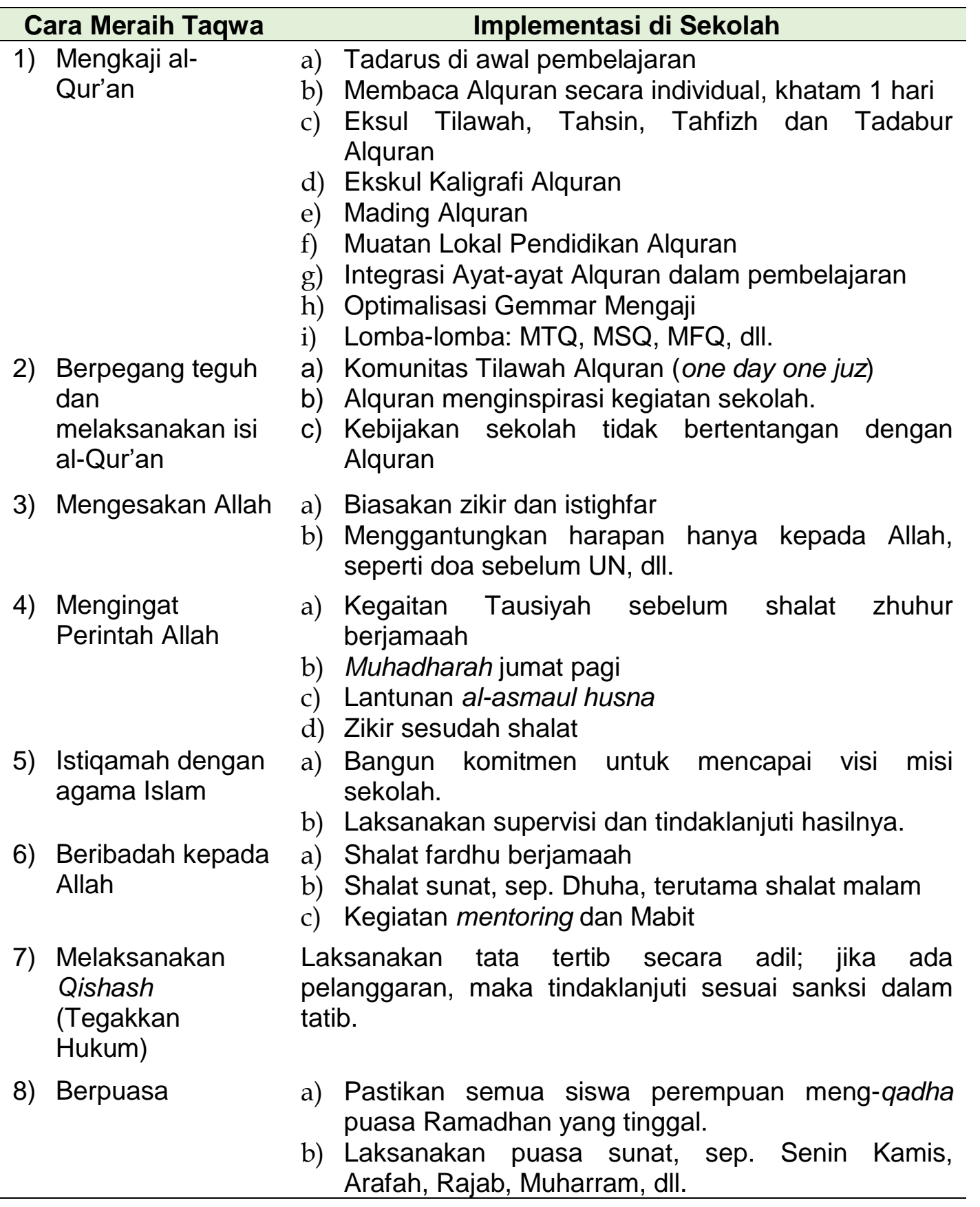

Tabel 1: Implementasi Pendidikan Islam Berbasis Takwa di Sekolah 
2. Surau sebagai labor pendidikan karakter

Idealnya, setiap sekolah memiliki surau (mushalla). Surau jangan hanya dijadikan sebagai tempat shalat semata, tetapi surau difungsikan sebagai labor karakter di sekolah. menjadikan surau sebagai laboratorium karakter dapat dilakukan dengan mengidentifikasi fungsi masjid era Rasulullah SAW lalu menerapkannya di sekolah.

Setidaknya ada tujuh fungsi masjid di zaman Rasulullah. ${ }^{42}$ Dari tujuh fungsi tersebut didesain pula kegiatan surau di sekolah yang berorientasi pada penguatan karakter, yaitu:

\section{Fungsi Masjid/Surau Implementasi di Sekolah}

1) tempat beribadah

a) hentikan segala aktivitas pembelajaran saat adzan berkumanang

b) shalat zhuhur berjamaah semua warga sekolah

2) tempat

c) shalat dhuha dan shalat sunat lainnya.

bermusyawarah

a) Basis kegiatan Rohis di sekolah

b) Ditata senyaman mungkin untuk tempat musyawarah

3) pusat pendidikan

a) pustaka surau berbasis akhlak

b) laboratorium PAI terintegrasi dengan surau

c) basis kegiatan mentoring.

4) tempat pengadilan

selain ruang $\mathrm{BK}$, bisa memberdayakan surau sebagai salah satu tempat menyelesaikan pertikaian dan permasalahan antar siswa

5) pusat pengembangan kehidupan sosial dan ekonomi umat

6) pusat kajian strategi perang dan politik

a) latihan mengelola infaq dan sedekah

b) pengembangan koperasi sekolah berbasis syariah

pusat kajian Islam dalam membentengi mentalitas pemuda dari serangan-serangan musuh berupa hedonisme, sekularisme, liberalisme, hingga ancaman narkoba, pornografi dan pornoaksi. Surau menjadi wadah untuk membina sikap mental yang tahan dari serangan tersebut.

7) tempat mengobatan Kegiatan surau menjadi terapi jiwa, dengan membentuk majelis zikir dan majelis ilmu.

Tabel 2: Implementasi Surau sebagai Labor Pendidikan Karakter

Di antara fungsi masjid masa Rasulullah di atas dapat diterapkan di surau sekolah sesuai dengan kondisi dan kebutuhan sekolah masing-masing. Dengan begitu diharapkan terbentuk peserta didik yang termasuk dalam kelompok rajulun qalbuhu mu'allaqun fil masajid (pemuda yang hatinya tergantung ke masjid). Inilah satu di antara tujuh kelompok yang kelak memperoleh naungan dari Allah di hari kiamat.

\footnotetext{
${ }^{42}$ M. Quraish Shihab, Wawasan Al-Quran: Tafsir Tematik Atas Pelbagai Persoalan Umat (Mizan Pustaka, 1996), hlm. 452.
} 
Berbagai kegiatan positif di atas harus dibiasakan secara konsiten dan kontiniu di sekolah. Dalam hal ini perlu penyusunan regulasi yang mengakomodir kegiatan tersebut. Keteladanan dan pembiasaan guru sangat dibutuhkan untuk membina karakter peserta didik, di samping pemahaman yang benar tentang ajaran Islam.

\section{Optimalisasi PAl pada PPK Berbasis Masyarakat}

PAI juga perlu diptimalkan dalam implementasi PPK berbasis masyarakat, di antaranya:

\section{Sekolah Orang Tua (islamic parenting)}

Orang tua/wali peserta didik perlu dihadirkan secara berkala di sekolah untuk mengikuti kegiatan islamic parenting, ${ }^{43}$ yaitu mempersiapkan orang tua agar memiliki pola asuh yang ideal menurut ajaran Islam dalam keluarganya. Sekolah menghadirkan para pakar, terutama islamic parenting sehingga orang tua memiliki pemahaman yang benar dalam menjalankan tugas mereka sebagai orang tua muslim dalam keluarga. Lebih dari itu, kegiatan parenting juga menjadi pusat konsultasi bagi orang tua dalam menemukan solusi atas berbagai persoalan yang dialami anaknya.

Kegiatan parenting yang dilakukan di sekolah merupakan bagian dari program "Pendidikan Keluarga" oleh Dirjend PAUD dan Dikmas. Kebijakan ini diperkuat dengan ditetapkannya Permendikbud Nomor 30 Tahun 2017 tentang Pelibatan Keluarga pada Penyelenggaraan Pendidikan. Salah satu fokus awal pelibatan keluarga adalah membentuk kelas orang tua (parenting) yang bertujuan untuk membangun kesadaran orang tua/wali akan pentingnya terlibat dalam pendidikan anak, termasuk mengembangkan lingkungan belajar yang aman, nyaman, dan menyenangkan. ${ }^{44}$ Kegiatan ini mesti dioptimalkan dengan materi yang diperkuat dengan kajian pendidikan Islam, sehingga orang tua memiliki pemahaman yang baik tentang mendidik anak sesuai ajaran Islam.

\section{Buku Penghubung Orang Tua}

Agar orang tua terlibat aktif terhadap pembinaan karakter peserta didik, sekolah perlu menyiapkan buku penghubung dengan orang tua ${ }^{45}$ yang berisi tentang catatan ibadah, seperti ibadah fardhu dan ibadah sunat. Temasuk catatan tilawah dan tahfizhnya. Buku catatan tersebut ditandatangani orang tua setiap hari dilaporkan ke sekolah secara berkala. Hal ini efektif dilakukan di tingkat sekolah dasar (SD dan SMP). Biasanya, buku hubung banyak dipraktikkan di Sekolah Islam Terpadu. ${ }^{46}$

\section{Pesantren Ramadhan dan Didikan Shubuh}

Khusus di Sumatera Barat, terdapat kebijakan pesantren Ramadhan di setiap bulan Ramadhan untuk SD, SMP, dan SMA/SMK ${ }^{47}$ serta didikan subuh

\footnotetext{
43 Secara etimologi, kata parenting dalam bahasa Indonesia sepadan dengan pengasuhan. Sedangkan education padanannya dalam bahasa Indonesia adalah pendidikan. Parenting education dapat diterjemahkan sebagai pendidikan pengasuhan. Sigit Purnama, Materi-Materi Parenting Education Menurut Pemikiran Munif Chatib (Yogyakarta: Universitas Islam Negri Sunan Kalijajaga, 2013), hlm. 25.

${ }^{44}$ Warisno, Kebijakan Direktorat Pembinaan Pendidikan Keluarga Tahun 2018 (Jakarta: Slide Direktorat Pendidikan Keluarga, Kemendikbud, 2018).

${ }^{45}$ Barsihanor Barsihanor, 'Kerjasama Antara Sekolah Dan Keluarga Dalam Pendidikan Karakter', Muallimuna: Jurnal Madrasah Ibtidaiyah 1, no. 1 (2015): 54-69.

${ }^{46}$ Ade Imelda Frimayanti, 'Latar Belakang Sosial Berdirinya Lembaga Pendidikan Islam Terpadu Di Indonesia', Al-Tadzkiyyah: Jurnal Pendidikan Islam 6, no. 1 (2015): 27-45.

47 Delmus Puneri Salim and Lies Kryati, 'POLITIK PENDIDIKAN AGAMA DAN PERUBAHAN
} 
untuk SD. ${ }^{48}$ Kegiatan pesantren Ramadhan telah diatur dalam Peraturan Gubernur Nomor 48 Tahun 2014 tentang Pedoman Penyelenggaraan Pembelajaran di Sekolah dan Madrasah pada Bulan Ramadhan. Dalam Pergub ini diamanahkan agar sekolah wajib menyelenggarakan pembelajaran di masjid/surau minimal seminggu selama Ramadhan, baik SD, SMP, maupun SMA/SMK. Kegiatan ini melibatkan masyarakat sekitar. Sedangkan Didikan Subuh untuk SD, khusus di Kota Padang, memerintahkan para guru agama untuk terlibat aktif ke masjid/mushalla dalam pelaksanaannya. Semua ini menjadi kegiatan penting dalam PPK bebasis masayarakat.

\section{Kerjasama dengan pendidikan diniyah}

Sekola sebaiknya bekerjasama dengan lembaga pendidikan Islam nonformal seperti pendidikan diniyah (TPQ, TPQ, MDTA, MDTW, dan MDTU) agar peserta didik aktif mengenyam pendidikan di lembaga ini. Lembaga ini berperan penting dalam melengkapi pemahaman siswa tentang agama sekaligus mendidik mereka mempraktikkannya. Bahkan lembaga ini juga berkontribusi dalam mendidik karakter peserta didik. ${ }^{49}$ Hanya saja, tidak semua siswa aktif belajar di lembaga ini. Karena itu, kebijakan pemerintah mewajibkan peserta didik aktif di lembaga pendidikan diniyah sangat diperlukan, sesuai dengan kondisi dan kultur masyarakatnya. Lembaga pendidikan diniyah bisa diintegrasikan ke sekolah, atau diselenggarakan secara terpisah seperti di masjid/mushalla.

\section{Penutup}

Pendidikan Agama Islam mesti dioptimalkan dalam mendidik karakter peserta didik, khususnya peserta didik yang beragama Islam. Apalagi konsep karakter yang diinginkan sesungguhnya bermakna akhlakul karimah. Tanpa agama, mustahil seseorang disebut berakhlak mulia. Sebab kata akhlaq memiliki akar kata yang sama dengan khaliq dan makhluk. Setiap makhluk bertuhan dituntut untuk memiliki akhlak sebagaimana yang diperintahkan Sang Khaliq.

Di sinilah pentingnya kreativitas guru PAI untuk mengembangkan peran strategis PAI di sekolah. PAI tidak saja berperan sebagai mata pelajaran, tetapi PAI bisa dikembangkan dalam berbagai kegiatan di sekolah, termasuk dalam program PPK. Guru PAI menjadi ujung tombaknya, tetapi harus didukung oleh pendidik muslim lainnya. Komitmen, kesatuan visi, dan keikhlasan semua pendidik muslim sangat diharapkan.

Jika PAI mampu menjalankan peran strategisnya di sekolah, maka tantangan era revolusi industri 4.0 bukanlah sebuah ancaman yang membahayakan, melainkan memberi peluang bagi eksistensi PAI membentuk karakter peserta didik. Revolusi Industri 4.0 justru mempertegas akan pentingnya agama bagi kehidupan manusia karena agama menuntun manusia menjadi insan al-kamil.

\footnotetext{
PRILAKU DI SUMATERA BARAT', El-Hekam: Jurnal Studi Keislaman 2, no. 1 (2018): 51-60.

48 Wahyu Wiratul and Sarwan Sarwan, 'FENOMENA IBADAH SHALAT ANAK DI DAERAH PESISIR PANTAI PADANG', Al-Hikmah: Jurnal Dakwah Dan IImu Komunikasi, 2018, 8-19.

49 Abdul Wahid, 'Integrasi Pendidikan Karakter Dalam Pembelajaran Di Madrasah Diniyah', Tarbawi: Jurnal Pendidikan Islam 15, no. 1 (2018).
} 


\section{Daftar Pustaka}

Al-Imam Abul Fida Isma'il Ibnu Kasir Ad-Dimasyqi. Tafsir Ibn Katsir, Penj. Bahrum Abu Bakar. Jilid 2. Bandung: Sinar Baru Algensindo, 2000.

Al-Imam Muhammad bin Ali bin Muhammad Asy-Syaukani. Tafsir Fathul Qadir, Terj. Amir Hamzah Fachruddin. Jakarta: Pustaka Azzam, 2011.

Ariandy, Mohammad. 'Kebijakan Kurikulum Dan Dinamika Penguatan Pendidikan Karakter Di Indonesia'. Sukma: Jurnal Pendidikan 3, no. 2 (2019): 137168.

Aziz, Roikhan Mochamad. 'Teori H Sebagai Ilmu Wahyu Dan Turats Dalam Islam', 2016.

Bagong, Suyanto. 'Metode Penelitian Sosial: Berbagai Alternatif Pendekatan, Jakarta: Kencana', 2005.

Balitbang Puskur Kemdikbud. Pengembangan Pendidikan Budaya Dan Karakter Bangsa: Pedoman Sekolah. Jakarta: Puskur Kemdikbud, 2010.

Barsihanor, Barsihanor. 'Kerjasama Antara Sekolah Dan Keluarga Dalam Pendidikan Karakter'. Muallimuna: Jurnal Madrasah Ibtidaiyah 1, no. 1 (2015): 54-69.

Dinas Pendidikan Provinsi Sumatera Barat. 'Pedoman Pengintegrasian Pendidikan Alquran Dan Budaya Alam Minangkabau Pada Mata Pelajaran Umum Sekolah Menengah Atas (SMA)'. Dinas Pendidikan Provinsi Sumatera Barat, 2017.

Frimayanti, Ade Imelda. 'Latar Belakang Sosial Berdirinya Lembaga Pendidikan Islam Terpadu Di Indonesia'. Al-Tadzkiyyah: Jurnal Pendidikan Islam 6, no. 1 (2015): 27-45.

Hamzah, Amir. 'Etos Kerja Guru Era Industri 4.0'. Literasi Nusantara, 2019.

Hawwa, Sa'id. 'Tarbiyatuna Ar-Ruhiyah, Penj'. Imam Fajaruddin, Surakarta: Era Adicitra Intermedia, 2010.

Hendarman, dkk (Tim Penyusun),. Konsep Dan Pedoman Penguatan Pendidikan Karakter Tingkat Sekolah Dasar Dan Menengah. Jakarta: Tim PPK Kemdikbud, 2016.

Hendra, Suwardana. 'Revolusi Industri 4.0 Berbasis Revolusi Mental'. Tuban: Universitas PGRI Ronggolawe, 2017.

Imaduddin, Muhamad. Membuat Kelas Online Berbasis Android Dengan Google Classroom: Terobosan Pembelajaran Era Revolusi Industri 4.0. Garudhawaca, 2018.

Indarti Suhadisiwi. Panduan Praktis Implementasi Penguatan Pendidikan Karakter (PPK) Berbasis Masyarakat. Jakarta: Pusat Analisis dan Sinkronisasi Kebijakan, Kemdikbud, 2018.

Jarir, Abu Ja'far Muhammad bin. 'Ath-Thabari'. Jami'al-Bayan at-Ta'wil Al-Qur'an, 2008.

Kemdikbud Menyiapkan Website PPK Terkait Dengan Pedoman, Praktik Baik, Dan Informasi Lainnya Yang Dapat Diakses Di Alamat: Cerdasberkarakter.Kemdikbud.Go.Id. n.d.

Kemdikbud, R. I. 'Konsep Dan Pedoman Penguatan Pendidikan Karakter Tingkat Sekolah Dasar Dan Sekolah Menengah Pertama'. Jakarta: Kementrian Pendidikan Dan Kebudayan RI, 2016.

Kosim, Muhammad. 'Pendidikan Karakter Berbasis Keislaman Dan Keindonesiaan'. Jurnal Al-Taujih: Bingkai Bimbingan Dan Konseling Islami 3, no. 2 (2017): 94-106.

Krippendorff, Klaus. 'Analisis Isi: Pengantar Teori Dan Metodologi, Terj'. Farid Wajidi. Jakarta: Rajawali Pers, 1991. 
Muhammad Kosim. 'Menjadi Guru Sejati'. Koran Padang Ekspres, 25 November 2017.

. 'Pendidikan Islam Di Era Revolusi Industri 4.0; Mempertegas Kesiapan Mahasiswa PAI Menjadi Pendidik Sejati, Makalah Seminar Seminar Nasional Forum Silaturahmi Mahasiswa (Forsima) PAI Se-Indonesia, Kamis, 20 Desember 2018 Di Gedung Serba Guna UIN Imam Bonjol Padang', n.d.

. 'Pendidikan Karakter Islami: Mempertegas Identitas Kader HMl'. Tarbiyah UIN Imam Bonjol Padang, 2018.

Muslih, Muslih, and Miftachul Ulum. 'PENDIDIKAN ISLAM ANTARA DUA ATAP: STUDI PADA KEBIJAKAN PENDIDIKAN ISLAM DI SEKOLAH DAN MADRASAH'. Mudir: Jurnal Manajemen Pendidikan 1, no. 2 (2019): 4865.

Nadia Fernanda. Panduan Praktis Implementasi Penguatan Pendidikan Karakter (PPK) Berbasis Sekolah. Jakarta: Pusat Analisis dan Sinkronisasi Kebijakan, Kemdikbud, 2018.

Permendikbud. 'Pasal 6 No.30 Tahun 2013', n.d.

Priatmoko, Sigit. 'Memperkuat Eksistensi Pendidikan Islam Di Era 4.0'. TA'LIM: Jurnal Studi Pendidikan Islam 1, no. 2 (2018): 221-239.

Purnama, Sigit. Materi-Materi Parenting Education Menurut Pemikiran Munif Chatib. Yogyakarta: Universitas Islam Negri Sunan Kalijajaga, 2013.

Salim, Delmus Puneri, and Lies Kryati. 'POLITIK PENDIDIKAN AGAMA DAN PERUBAHAN PRILAKU DI SUMATERA BARAT'. El-Hekam: Jurnal Studi Keislaman 2, no. 1 (2018): 51-60.

Shaleh, HM Ashaf. Takwa: Makna Dan Hikmahnya Dalam al-Qur'an. Penerbit Erlangga, 2002.

Shihab, M. Quraish. 'Tafsir Al-Misbah'. Jakarta: Lentera Hati 2 (2002).

- Wawasan Al-Quran: Tafsir Tematik Atas Pelbagai Persoalan Umat. Mizan Pustaka, 1996.

Sofie Dewayani. Panduan Praktis Implementasi Penguatan Pendidikan Karakter (PPK) Berbasis Kelas. Jakarta: Pusat Analisis dan Sinkronisasi Kebijakan, Kemdikbud, 2018.

Suprayogo, Imam, and Tobroni. Metodologi Penelitian Sosial-Agama. Remaja Rosdakarya, 2001.

Syed M. Naquib al-Attas. Konsep Pendidikan Dalam Islam. Bandung: Mizan, 1988.

Tafsir, Ahmad. IImu Pendidikan Dalam Perspektif Islam (Bandung Remaja Rosdakarya, 2008, Cet. Ke, n.d.

'Undang-Undang Republik Indonesia Nomor 17 Tahun 2007 Tentang Rencana Pembangunan Jangka Panjang Nasional', 20252005.

Wahid, Abdul. 'Integrasi Pendidikan Karakter Dalam Pembelajaran Di Madrasah Diniyah'. Tarbawi: Jurnal Pendidikan Islam 15, no. 1 (2018).

Wardani, Ratna. '21st Century Educator: Menyongsong Transformasi Pendidikan 4.0'. In Porsiding Seminar Nasional Dinamika Informatika Senadi. Yogyakarta: Universitas PGRI Yogyakarta, 2018.

Warisno. Kebijakan Direktorat Pembinaan Pendidikan Keluarga Tahun 2018. Jakarta: Slide Direktorat Pendidikan Keluarga, Kemdikbud, 2018.

Wiratul, Wahyu, and Sarwan Sarwan. 'FENOMENA IBADAH SHALAT ANAK DI DAERAH PESISIR PANTAI PADANG'. Al-Hikmah: Jurnal Dakwah Dan IImu Komunikasi, 2018, 8-19.

Yudiani, Ema. 'Komparasi Paradigma Psikologi Kontemporer Versus Psikologi Islam Tentang Manusia'. Jurnal Ilmu Agama: Mengkaji Doktrin, Pemikiran, Dan Fenomena Agama 15, no. 1 (2014): 79-90. 
Pengembangan Bahan Ajar Tahsinul Qiro'ah Berbasis An-Nahdliyah Untuk Meningkatkan Ketrampilan Membaca Al-Qur'an 